\title{
IMPLEMENTASI MANAJEMEN MUTU TERPADU DALAM SISTEM MANAJEMEN SARANA DAN PRASARANA
}

\author{
Ronius Lase \\ email: ronnylase89@gmail.com \\ Universitas Negeri Malang, Jalan Semarang No. 5 Malang
}

\begin{abstract}
Abstrak: Penelitian ini bertujuan untuk menganalisis implementasi manajemen mutu terpadu dalam sistem manajemen sarana dan prasarana. Penelitian ini menggunakan pendekatan deskripsi. Populasi dalam penelitian ini adalah pelanggan eksternal dalam satuan pendidikan, yaitu peserta didik. Data dikumpulkan melalui hasil observasi dengan menggunakan kuisioner, dan dianalisis dengan menggunakan deskripsi. Dari penelitian ini ditemukan bahwa: (I) sarana dan prasarana yang tersedia di sekolah tersebut, belum memenuhi kepuasan peserta didik, sehingga tingkat ketidakpuasan peserta didik masih tinggi; (2) membutuhkan dukungan dari yayasan dalam memenuhi kebutuhan sekolah.
\end{abstract}

Kata Kunci: Manajemen Mutu Terpadu, Sarana dan Prasarana, Kepuasaan Pelanggan

\section{PENDAHULUAN}

Perkembangan globalisasi saat ini tidak bisa dibendung lagi, dimana telah memasuki ke seluruh aspek kehidupan manusia, termasuk dalam bidang pendidikan. Dengan adanya perkembangan ini, menuntut setiap satuan pendidikan untuk tetap mempertahankan bahkan meningkatkan mutu satuan pendidikan. Orang tua, peserta didik, dan masyarakat pada umumnya sebagai pengguna jasa pendidikan, memberikan harapan yang besar terhadap dunia pendidikan yang bermutu. Berbagai macam upaya yang sedang, dan akan dilakukan oleh masingmasing satuan pendidikan dasar untuk memenuhi tuntutan dunia pendidikan yang berkualitas.

Manajemen mutu dalam dunia pendidikan dapat dipahami dalam pengertian "mengutamakan peserta didik" atau "program perbaikan sekolah" yang dapat dilakukan secara kreatif dan konstruktif. Dalam hal ini, mutu terpadu dapat mengubah kultur sekolah, sehingga peserta didik dan orang tua menjadi tertarik terhadap satuan pendidikan tersebut, dimana terus-menerus melakukan perubahan dalam perbaikan program-program. Dalam proses pendidikan yang bermutu sangat berperan penting berbagai input, misalnya bahan mengajar, metodologi, sarana sekolah, dukungan administrasi, sarana dan prasarana, serta sumber daya lainnya (Zazin, 2017:57).

Sampai saat ini, pandangan semua orang hampir sama bahwa pendidikan dianggap sebagai sebuah investasi yang sangat penting dalam meningkatkan kualitas manusia. Namun, mutu pendidikan tidak hanya dapat dilihat dari lulusannya yang berkualitas, akan tetapi dari proses dan faktor penunjang yang ada. Dengan adanya pemahaman ini, sehingga orang tua cenderung memilih satuan pendidikan yang memiliki fasilitas yang memadai untuk proses pendidikan anak-anaknya. Dari pemahaman pengguna jasa pendidikan, mutu dapat dipahami sebagai sebuah kepuasaan yang diterima oleh pengguna jasa pendidikan, bahkan melampaui keinginan dan kebutuhan pengguna jasa tersebut (Sallis, 20I5;46).

\section{METODE}

Penelitian ini merupakan peneltian deskriptif dalam bentuk survey. Dalam penelitian ini, penulis menganalisis kepuasan pelanggan dalam hal ini peserta didik SMPKA Malang Malang. Populasi dalam penelitian ini peserta didik SMPKA Malang berjumlah 125 orang. Teknik pengumpulan data yang digunakan oleh penulis dalam penelitian ini adalah dengan menyebarkan kuisioner dalam bentuk google formulir. 


\section{HASIL DAN PEMBAHASAN}

Kualitas menurut Crosby adalah conformance to requiretment, yaitu sesuai dengan yang diisyaratkan atau distandarkan. Menurut Deming, kualitas adalah kesesuaian dengan kebutuhan pasar/konsumen. Sedangkan menurut Juran, kualitas adalah fitness for us (dalam Nasution, 20I5:2). Dari pandangan tersebut dapat disimpulkan bahwa kualitas itu sesungguhnya merupakan sebuah standar yang sesuai dengan kebutuhan pengguna produk tersebut. Dalam dunia pendidikan, pemerintah telah menetapkan sebuah standar pendidikan yang dituangkan dalam Standar Nasional Pendidikan (SNP) yang terdiri dari 8 standar. Standar Nasional Pendidikan (SNP) memiliki fungsi dan tujuan untuk mewujudkan pendidikan yang bermutu, sebagaimana dikatakan dalam PP No. 19 Tahun 2005 pasal 3 dan 4 bahwa SNP berfungsi sebagai dasar perencanaan, pelaksanaan, dan pengawasan pendidikan dalam mewujudkan pendidikan nasional yang bermutu. Tetapi, Standar Nasional Pendidikan ini merupakan kriterian minimum saja dalam melaksanakan sistem pendidikan di seluruh wilayah Republik Indonesia (Barnawin \& Arifin, 2017:42).

Seorang tokoh Manajemen Mutu Terpadu/TQM bernama Crosby (dalam Sule, 20 I8: 140) menyatakan bahwa Manajemen Mutu Terpadu/TQM adalah strategi dan integrasi sistem manajemen untuk meningkatkan kepuasan konsumen, mengutamakan keterlibatan seluruh manager dan pegawai, serta menggunakan metode kuantitatif. Oleh karena itu, Crosby memberikan standar kinerja yang harus digunakan dalam seluruh aspek yaitu zero defect. Strategi yang diterapkan dalam menggunakan manajemen mutu terpadu dalam dunia pendidikan adalah satuan pendidikan memposisikan diri sebagai lembaga yang memberikan pelayanan (service) jasa sesuai harapan pelanggan (customer). Hal ini selaras dengan konsep yang dikemukakan oleh Deming, yaitu "3 C" yang berfokus pada Customer, Culture and Capacity, untuk melakukan perbaikan yang berkesinambungan (David Wijaya, 2008: 86 - jurnal pendidikan penabur).

Salah satu unsur yang sangat utama dalam TQM adalah fokus pada pelanggan, dengan sebuah prinsip bahwa segala kebutuhan pelanggan diusahakan semaksimal untuk dapat memberikan kepuasan dalam semua aspek. Pelanggan dalam hal ini adalah pelanggan internal maupun pelanggan eksternal. Jadi, pada dasarnya TQM merupakan pemuasan persyaratan yang diinginkan oleh pelanggan (Nasution, 2015: 24). Dalam konteks pendidikan siswa dapat dikategorikan sebagai pelanggan internal tetapi juga dapat dikatagorikan sebagai pelanggan eksternal. Sebagai katagori pertama manakala siswa ikut berperan dan berkontribusi bersamasama pihak sekolah menghasilkan produk atau jasa. Dilain sisi siswa dapat dikatagorikan sebagai pelanggan eksternal manakala mereka pasif hanya menerima begitu saja dan tidak berperan dalam menghasilkan produk atau jasa sekolah (Sutarto, 2015: 37).

Supaya lebih memahami tentang mutu, Zazin (2017:56) memberikan penjelasan tentang manajemen mutu terpadu dan hubungannya dengan pelanggan dalam bentuk gambar berikut ini: 


\section{MUTU}

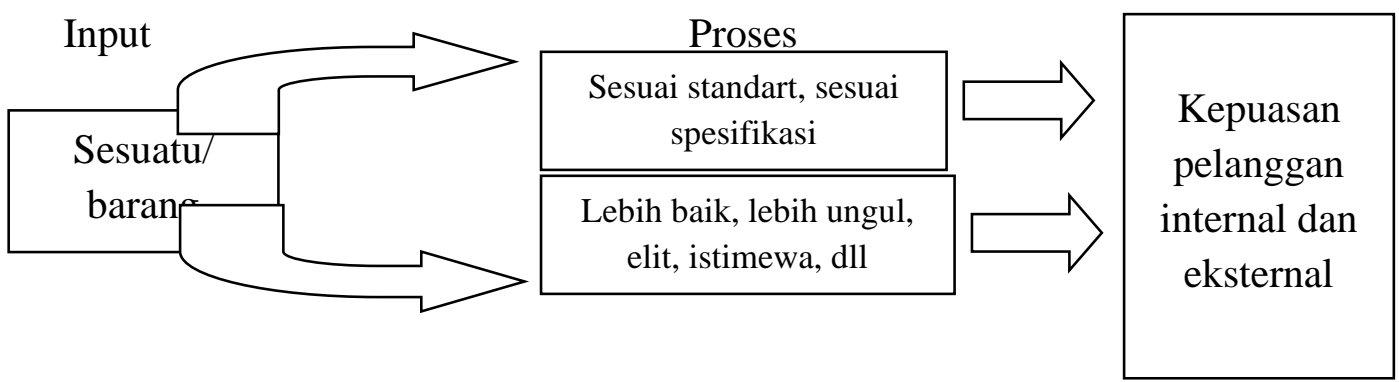

5 karakteristik yang diilustrasikan dalam bentuk pilar, yaitu (I) fokus pada kostumer; (2) keterlibatan total; (3) pengukuran; (4) komitmen; (5) perbaikan berkelanjutan. Keberhasilan dalam menerapkan TQM tersebut di sekolah, dapat diukur tingkat kepuasan pelanggan (internal \& eksternal). Sekolah dikatakan berhasil dalam menerapkan TQM apabila memberikan pelayanan sesuai yang diharapkan dan diinginkan oleh para pelanggan. Hal tersebut bisa diukur dengan melihat dan mendapatkan respon dari pelanggan:

I. Siswa puas dengan layanan sekolah, tentang pelajaran yang diterima, perlakuan guru, pimpinan, puas dengan fasilitas, siswa menikmati situasi sekolah (nyaman).

2. Orang tua merasa puas dengan pelayanan yang diberikan oleh sekolah terhadap anaknya, baik dari segi perkembangan anak, maupun dari segi program yang dijalankan.

3. Pihak pemakai atau penerima lulusan merasa puas karena menerima lulusan yang berkualitas dan sesuai harapan.

4. Pendidik dan Tenaga Kependidikan merasa puas dengan pelayanan sekolah dalam hal pembagian tugas, hubungan antara guru dan kepala sekolah, gaji yang diterima (Zazin, 2017: 64-65).

Menjadi lembaga pendidikan yang bermutu, yang diharapkan oleh pelanggan salah satunya adalah ketersediaan sarana-prasarana seperti yang diuangkapkan oleh Zazin. Menurut Ismaya (20I5: I 22), sarana dan Prasarana merupakan fasilitas pendukung yang dapat menunjang proses kegiatan dalam organisasi. Sarana merupakan perlengkapan yang sifatnya dapat digunakan secara langsung, sedangkan prasarana merupakan fasilitas pokok yang sifatnya mempunyai masa pakai yang cukup lama. Dalam PP No. 19 tahun 2005 pasal 42 mengamanatkan tentang sarana dan prasarana sebagai berikut:

a. Setiap satuan pendidikan wajib memiliki sarana yang meliputi perabotan, peralatan pendidikan, media pendidikan, buku dan peralatan lain yang menunjang proses belajar yang teratur dan berkelanjutan.

b. Setiap satuan pendidikan wajib memiliki prasarana yang meliputi lahan, ruang kelas, ruang pimpinan satuan pendidikan, ruang pendidik, ruang laboratorium, ruang tata usaha, ruang perpustakaan, ruang bengkel kerja, ruang unit produksi, ruang kantin, instalasi daya dan jasa, tempat berolahraga, tempat ibadah, tempat bermain, tempat rekreasi, dan tempat lain yang menunjang proses pembelajaran yang teratur dan berkelanjutan.

Berdasarkan respon peserta didik SMPKA Malang terhadap kuisioner yang telah penulis sebarkan, maka ditemukan bahwa kepuasaan peserta didik terhadap pelayanan dan sarana yang disedikan oleh SMPKA Malang termasuk rendah. Hal ini dapat dibuktikan dari persentasi berikut ini:

I. Apakah belajar di SMPKA Malang menyenangkan!

Senang $=39,2 \%$

Tidak Senang $=60,8 \%$

2. Pada saat proses KBM, Apakah anda nyaman belajar di kelas anda! 
Nyaman $=37,6 \%$

Tidak nyaman dan biasa-biasa $=62,4 \%$

3. Bagaimana pendapatmu tentang meja dan kursi di SMPKA Malang Malang!

Banyak yang Rusak $=82,4 \%$

Tidak Nyaman $=6,4 \%$

Bagus $=11,2 \%$

4. Apakah banyak sarana dan prasarana yang tersedia di SMPKA Malang!

Banyak $=56 \%$

Sedikit $=44 \%$

Dari persentasi respon peserta didik tersebut diatas, maka solusi yang dapat ditawarkan kepada pihak sekolah ataupun yayasan adalah saat ini sangat diperlukan pemenuhan kebutuhan akan sarana dan prasarana yang dibutuhkan oleh satuan pendidikan tersebut, guna meningkatkan kualitas pendidikan, dan kualitas sarana dan prasarana. Dalam menyelesaikan akan masalah tersebut dapat menggunakan model Deming, sebagai berikut:

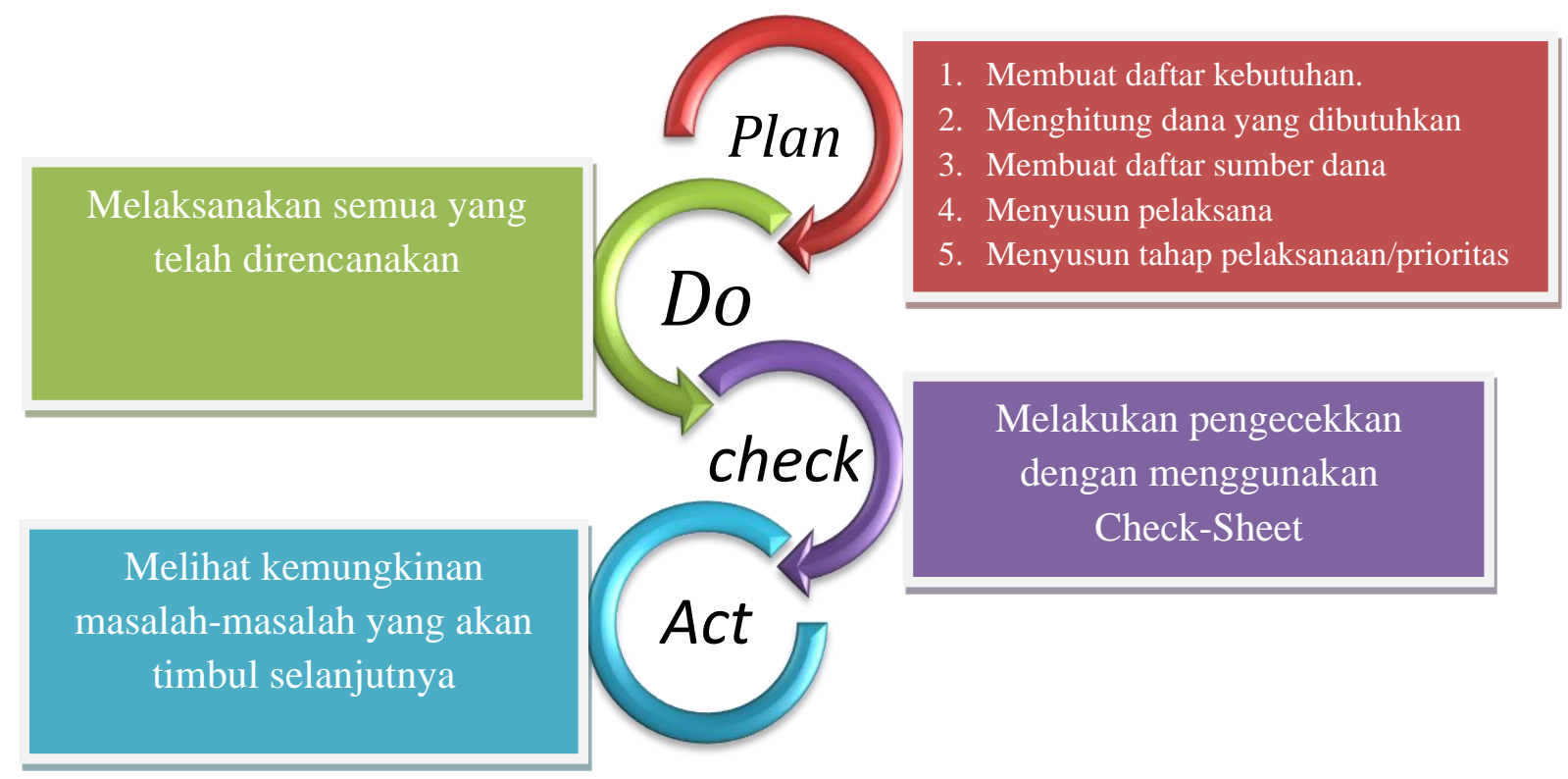

\section{KESIMPULAN}

Dari penjelasan penulis diatas, maka dapat disimpulkan bahwa sarana dan prasarana sangat penting dalam merapkan Manajemen Mutu Terpadu di satuan pendidikan. Walaupun hanya sebagai penunjang, tetapi pengaruhnya sangat berdampat dalam setiap proses pendidikan yang berlangsung. Oleh karena itu, agar kepuasan pelanggan terpenuhi dalam proses pendidikan dan meningkatkan mutu pendidikan, maka sekolah harus berusaha untuk memenuhi kepuasaan pelanggan, dalam hal ini peserta didik. Dalam memenuhi akan kebutuhan ini, dapat dilakukan secara bertahap menurut skala prioritas kebutuhan, dan sesuai kemampuan satu pendidikan dalam hal keuangan yang ada.

\section{DAFTAR RUJUKAN}

Arcaro, Jerome S. 2006. Pendidikan Berbasis Mutu: Prinsip-prinsip Perumusan dan Tata Langkah Penerapan. Yogyakarta: Pustaka Pelajar.

Barnawin \& Arifin, M. 2017. Sistem Penjaminan Mutu Pendidikan - Teori \& Praktik. Yogyakarta: Ar-Ruzz Media. 
Hp, Sutarto. 20I5. Manajemen Mutu Terpadu (MMT-TQM) Teori dan Penerapan di Lembaga Pendidikan. Yogyakarta: UNY Press.

Ismaya, Bambang. 20I5. Pengelolaan Pendidikan. Bandung: PT Refika Adimata.

Nasution, M. Nur. 2015. Manajemen Mutu Terpadu. Bogor: Ghalia Indonesia.

PP No. 19 tahun 2005 tentang Standar Nasional Pendidikan.

Sallis, Edward. 2015. Total Quality Management in Education. Yogyakarta: IRCiSoD.

Sule, Ernie Tisnawati., Priansa, Donni Juni. 2018. Kepemimpinan dan Perilaku Organisasi (Membangun Organisasi Unggul di Era Perubahan). Bandung: PT Refika Adimata.

Wijaya, David. 2008. Implementasi Manajemen Mutu Terpadu dalam Penyelenggaraan Pendidikan di Indonesia. Jurnal Pendidikan Penabur, 84-94.

Zazin, Nur. 2017. Gerakan Menata Mutu Pendidikan: Teori \& Aplikasi. Yogyakarta: Ar-Ruzz Media. 